\title{
Finanční krize přichází vždy na podzim
}

\section{Vážení čtenáři,}

čtvrté číslo časopisu Českého finančního a účetního časopisu vychází vždy na podzim. A na podzim, jak se zdá, občas přichází i finanční krize. I když bych jinak nerad jako předseda redakční rady tohoto časopisu obě dvě skutečnosti spojoval dohromady.

Pohled do historie ř́iká, že Velká hospodářská krize vypukla na podzim roku 1929. Ještě 3. záŕí toho roku ceny akcií rostly a finanční analytici očekávali slibnou úrodu svých investic. O den později se růst cen zastavil a o další den později již některé ceny začaly klesat. Všichni však věřili, že se jedná jen o dočasný pokles. V ř́ijnu se však během několika dnů trh zhroutil. Lidová tvořivost těmto dnům přinesla označení: černý čtvrtek (24. říjen), černé pondělí (28. říjen) a černé úterý (29. ř́jen). Další krach akcií se uskutečnil rovněž jiný poklidný podzimní den, 19. října 1989, jenž později získal rovněž př́ivlastek jako další černé pondělí,. A letošní podzim? S využitím upraveného citátu Antonína Důry ${ }^{1}$ si dovoluji konstatovat, že „tento způsob podzimu zdá se mi poněkud nešt’astným.“ Dne 7. září roku 2008 převzal americký Federal Housing Finance Agency kontrolu nad dvěma hypotečními agenturami: Fannie Mae (Federal National Mortgage Association) a Freddie Mac (Federal Home Loan Mortgage Corporation) z důvodu jejich nízké likvidity. O týden později, dne 15. zárí, požádal Lehman Brothers Holdings o prohlášení bankrotu podle kapitoly 11 zákona o bankrotech (Bankruptcy Code). A poté již ceny akcií začaly připomínat jízdu na splašeném býku. Jelikož však se jako býčí trh (bull market) obvykle označuje jako trh doprovázený růstem cen akcií, měli bychom spíše hovořit o útěku před medvědy z vysokých hor směrem dolů do údolí či $\mathrm{v}$ některých prrípadech o skoku rovnou do propasti.

Čím to, že podzim představuje roční období, před kterým by se měli finanční investoři ruku $\mathrm{v}$ ruce $\mathrm{s}$ finančními analytiky trást jako před zlým svědomím. Možná právě proto, že jejich finanční svědomí nemuselo být zcela čisté. Svým klientům neustále slibovali velké výdělky, a to ještě navíc se zanedbatelným rizikem. V létě si potom užívali letních radovánek a snění o rostoucích a tudíž radostných zítřcích akciových kurzů. Avšak sluníčko na pláži jim současně vyřadilo mysl z provozu. A tak se teprve na podzim začínají probouzet, někteří $\mathrm{k}$ jejich vlastní velké škodě až prŕíliš dlouho.

Všichni se ted' ptají, jak dlouho bude trvat tento finanční podzim a zda následující finanční zima nebude ještě horší. Toto je zcela zajisté jedna $z$ otázek, kterou by rychle měla začít řešit $i$ finanční teorie. Jenže, neměla by třeba sama finanční teorie ještě předtím zpytovat své vlastní teoretické svědomí? Když jsem pročítal příspěvky přednesené na výroční schůzi American Economic Association v lednu 2008, našel jsem jen jeden př́spěvek věnovaný problematice hypotečních úvěrů, které se nakonec ukázaly být hlavní příčinou současné finanční krize. Byla tedy finanční teorie doopravdy dobrým a poctivým rádcem, který varoval svět před budoucími problémy? Nebo svými publikacemi majícími charakter pohádek o hodném trhu krizi naopak jen prohloubila a uspíšila? Anebo byla jen nestranným, ale potom také mlčícím pozorovatelem? Jinými slovy objevuje se otázka, zda finanční krize není současně i krizí finanční teorie. 1 Postava z knihy Rozmarné léto od Vladislava Vančury, první vydání z roku 1926 vydal v Praze Jan Fromek.
Původní citát samozřejmě zněl: Tento způsob léta zdá se mi poněkud neštastným. 
Ano, vím, že byli, jsou a budou vždy jak dobří tak i špatní teoretici. Ale proč ti dobř́ teoretici nebyli dostatečně slyšet? Nepovažuji tuto otázku za akademickou, ale naopak za vrcholně praktickou. Pokud se nám nepodaří přesvědčit svět o naší užitečnosti, tak přijdeme o důvod naší existence.

Aby však závěr nebyl tak pesimistický, dovolím si jednu ještě citaci, tentokráte $\mathrm{z}$ filmu Byl jsem při tom. ${ }^{2}$ Slovy zahradníka Chance: „Na zahradě máme různá roční období. Nejdřív přichází jaro a léto, poté následuje podzim a zima. A pak máme opět jaro a léto." $\mathrm{S}$ citacemi filmových hrdinů si nicméně ve finanční teorii př́liš dlouho nevystačíme. Ačkoliv Mr. Chance zde vystupující jako prostoduchý zahradník je naprostým omylem považován za finančního odborníka, a to tak uznávaného odborníka, že se na jeho předpovědi odvolává i samotný prezident U.S.A.

Tak tedy ještě jednou: po podzimu přichází zima, a po zimě následuje jaro a léto. ${ }^{3}$

\author{
prof. Ing. Petr Marek, CSc. \\ předseda redakční rady Českého finančního a účetního časopisu \\ a řešitel výzkumného záměru \\ Rozvoj účetní a finanční teorie \\ a její aplikace $v$ praxi z interdisciplinárního hlediska
}

\footnotetext{
2 Film Byl jsem při tom (angl. Being There) zfilmoval v r. 1979 režisér Hal Ashby s Peterem Sellersem v hlavní roli.

3 Pro pesimisty ještě dovětek: po každém létě vždy následuje podzim a zima.
} 